\title{
The Lust and its Management Strategies in Saadi's Bustan
}

\author{
Leila Khajehpour $^{1}$, Ali Reza Yousefi*2 ${ }^{* 2}$ Narges Keshtiaray ${ }^{3}$ \\ 1. Ph.D. Student in Philosophy of Education, Department of educational sciences, Isfahan (Khorasgan) Branch, \\ Islamic Azad University, Isfahan, Iran. \\ 2. Professor, Department of Medicine, Medical Education Research Center, Management of Medicine Studies and \\ Development, University of Medical Sciences, Isfahan, Iran. * Corresponding author \\ 3. Associate Professor, Department of educational sciences, Isfahan (Khorasgan) Branch, Islamic Azad University, \\ Isfahan, Iran.
}

\begin{abstract}
This study is aimed at investigating the concept of lust emotion and its management strategies in Saadi's Bustan. The data collection method is the descriptive-analytical method, and the analyzed sample is Saadi's Bustan. The results suggest that the humans control himself and try to bypass his animal aspect. His recommendations regarding the control of physical and sexual passions include: eating less and leaving self-indulgence, contentment and leaving greed, remembering death and seizing life, having shame before the Lord of the universe, struggling with carnality, putting the reason and wisdom as ruling powers, not being disappointed of returning to the right way and doing repentance, and the direct and explicit way of forbearance and marriage and choosing the right and pious partner to control sexual lust. The result: Saadi has known the human dignity values restricted to the humanistic encounters that arose from the human spirit. From his perspective, the adornment of the human body and appearance is not the criterion of humanity, and if human life is based on eating, sleeping, anger, and lust, so there is no difference between humans and animals. He knows the severe adherence to mundane world as the seduction of self and downgrade to animal levels believes that the suppression of this fulsome self helps the human beings to achieve the true human position and the nearness of the soul to God.
\end{abstract}

Keywords: Lust, Lust Management, Saadi’s Bustan.

\section{Introduction}

Instincts are considered as main concepts in evolutionary psychology (Johnson, Carroll, Gottschall, \& Kruger, 2008). There have been many instincts and emotions in human nature the roles of which are unmistakable in human life. The human life in all stages, even at infancy stage, is influenced by affections and emotions and his personal and social behavior is determined by them. The physical and the mental health of the person are bound to emotional health (Qaemi, 1991). Extremes in emotion lead people to conflict, aggression, anger, hatred, and anxiety, which threatens people's mental and emotional health in a serious and uncontrolled way (Ahmadi, 2001). The verses and narrations give the fact that emotions should be controlled and in case of conflict with other values, they can be preferred everywhere; but it is necessary to fight extremes in emotions and control them by ration (Misbah Yazdi, 2005).

The aim is only met by a true understanding of how to express and control emotions (Shariatmadary, 2005). Affection's management gives humans spiritual and mental balance, it assesses conflicting needs and wants and, if necessary, meets some of them and guide them in an appropriate direction and in fact, it considered as the background for self-esteem.

In the terminological definition of "affections" we can say that it is the plural form of affection. The word (in Arabic) is the feminine word without "T" meaning desire, restorer, and kind (Yousefi, Keshtiaray, \& Khajehpour, 2016). In English language, it is shown with the word "affection, " and it is used in a state in which the affection is aligning with thought (Farmahini Farahani, 1999). In terminology, affections including a spectrum that introduces a set of stimuli, 
behaviors, moods, and positive and negative experiences such as love, joy, anger, and misery (Plutchik, 1980). Moreover, it is experienced as a very pleasant or a very unpleasant response (Farmahini Farahani, 1999). It is known with descriptive words such as excitement, emotion, mood, emotional habits, static emotion and positive and negative emotional tendencies and it can be accurately defined due to its broad scope (Lotfabadi, 2007; Misbah, 1995).

Affection management is a subject that is used in the last decades and is generally used with various factors such as affection control, emotional control, emotional intelligence and so on in all of which affection control skills is considered as common and affects various aspects of life, interpersonal interactions, psychological and mental health and the physical well-being of the person (Dunham, 2008). Affection control is not possible unless we are familiar with basic emotions such as anger, fear, anxiety, happiness, surprise, sadness, disgust and love as well as enough knowledge about excitement levels, phases, physical, emotional and cognitive indications and their behavior, positive and negative emotions and their strong and weak points. Knowing about emotions gives us analysis and control power and whatever the knowledge (power) is, we have improved towards affection management and control and the betterment of interpersonal relationships, and in general, we have made a significant contribution to the successfulness of our lives (Al-Ghazzali, Daniel, \& Field, 2015). The meaning of the affection control skill is that the person learns how to diagnose his emotions in different situations and express or control those emotions (Gross, 1998). Some emotions have many effects on physical and mental abilities, and they can disorganize the organization of the mind and body and interfere to the compatibility of human beings with the environment. Lust is one of the most powerful forces and instincts inherent in human existence (Ali \& Al-Owaihan, 2008).

The expert philologist, Ragheb, has stated his idea regarding the meaning of lust as lust is the attraction of the self towards what it wants and this is of two kinds: true tendency and false tendency. Positive lust and tension is the necessary and natural will and tendency in human existence (such as desire for food when hungry, asking for water when thirsty and desires such as loving women, children and so on), but the false and negative lust is that human beings love things and be drawn toward things that are not essential to the body and the structure of existence and it is in the realm of debauchery and revelry. Among desires, lust shows itself more than others and according to psychiatrists: "lust is among the strongest human instincts, and the contemporary and history confirms that the source of many social event storms has been caused by this instinct" (Rahnema, 2000). In fact, we can never escape from negative feelings because feelings are an integral part of life and affect our growth and development (Härtel, Kibby, \& Pizer, 2004). It is better to reduce the reactive effects of emotions instead of their occurrence to have enough chance for better decision making, providence, and creativity (Bar-On, 2006).

Having lustful desire is one of the aspects of human life, and nobody can suppress it; since the suppression of the natural desires of human beings including anger and lust means going beyond human instinct which has various harmful effects on the person. The people who suppress their natural desires are sick, and they suffer from lack of health and personality balance. What the Islamic culture reproaches is not following via media rule and going into extremes (Rahnema, 2000).

One of the eternal and honorable assets of Iranians is the Muslim poets, speakers and mystic's poems and the secret of the viability of many of these leaders using the words of God the 
almighty and Imams in their writings. The words of Saadi have an eloquent expression of affection that provides backgrounds that the person can identify affection reasonably and in association with other aspects of personality and pave the way for the sublime human affections. The issues related to psychology in the Bustan of Saadi are among issues that require precise explanation and interpretation to be identified and explored by all their dimensions and the deep concepts of affection and their management. Saadi is a moral teacher, and his moral preaching is derived from his religious beliefs (Rajab Nasab, 2014). It is written about him that he is the greatest didactic and moral Iranian poet (Safa, 2000).

Alongside with the education of body, mind, intellect, will, and instinct, the management of affections and affection education is an issue which is being mentioned both in Western psychology and Islamic religious texts, including holy Qur'an and the Sunna of the Prophet (PBUH) in a hadith of Imams (PBUT). In this study, in the examination and analysis of Saadi's Bustan masterpiece in a new and applied way, we are to answer the question that what is the viewpoint and educational strategies of Saadi in the discussion of how to manage affection and the control and education of lust. Using moral and educational thoughts of this great teacher of Iranians regarding the concept and symbols of affection, management and strategies to control them in the face of social issues and problems can be an appropriate model for all the society members.

Affection from the viewpoint of Saadi Social life, especially the deep understanding of the value of social coordination and living with people and have a relationship with them theoretically and actually, being sensitive to the pains of people and endeavor for the well-being of people have an important position in the depth of Saadi's thought and sense. The profound human attitude of poet and his sensitive soul does let him see the indifference and recount to the sufferings of the people; and the poet, in all these cases, talks of compassion and empathy with an emotional expression eloquently and translucency (Torabi, 1997). Saadi's Bustanpurifies, the man wherever possible. Human emotions, empathy, love, and dependence of people together is shown in different ways. Affection is an essential condition in ethics and ethics and emotion are necessary for each other and bound together, and Saadi and Saadi's Bustan is a window into the world of emotions and moralities. As was mentioned earlier, emotion is a necessary condition in ethics since the moral behavior of each man is based on the empathy; a force that causes the man to participate in the happy and sad moments of others. "Saadi really adhered to the theory of moral emotions and gives a great deal of attention to empathy" (Saadi, 2006).

The emotional aspects of personality can be seen in abundance in the poems of Saadi that can be as a reason, alongside with other reasons, for the more credence of the poems of this poet among people. About Saadi's poetry, Foroughi states that he is all kindness and his loving aspect is very strong so that Saadi's existence is interwoven with love (Saadi, 2006). Saadi has mentioned to four main emotions in his poetry including sadness, happiness, fear, and anger and briefly mention unessential, combined or complex emotions of love in his poems (as cited in QaraMaleki, 2008). We should remember that Saadi is qualified to religious tolerance (Rypka, 2013). Saadi is the heir of a culture that is an amalgamation of Arab and Islamic culture, and affection is apart from emotion according to Islamic education. Affection is what is been mentioned in Western psychology and has physiologic and biologic roots such the feeling of cold or heat and thirst and anger and fear, depression and happiness. Islam, besides confirming the 
above, proposes another kind of human perception that has knowledge root named as the excellent human affection which is special to human life. Reason gives value to the truth, beauties, values, and certainties that are strongly appealing. Fascinations and desires that value reasons show toward them and create a spiritual state in the heart is called affection. The examples are the affection of devotion and self-sacrifice, the affection of courage and the affection divine love. Such sentiments only have knowledge roots. Familiarity, affection, helping the poor, the weak and children, courage, loving, sacrificing, forgiveness, grief, passion, and love are all the examples of excellent human affection (Senobary, 2011).

\section{Lust in Bustan}

"Lust" has the general sense and concept and includes any kind of love, joy, and willingness to experience joy and desires without being devoted to sexual lust although they are sometimes used as sexual meaning. In the holy Quran, the concept is been used in 11 cases as its general term, and it is only used in 2 cases as its especial meaning. In Islamic hadith and the words of moral teachers, it is mostly used in the general term and contrast, the word "modesty" is used as meaning self-constraint and ignoring the sinful materialistic joys. "Lust" is in the opposite direction to "modesty." "Modesty" has general and special meaning as well. Its general term is self-restraint against any extreme sensual desire, and its special term is self-restraint against the profligate sexual desires. "Modesty" is one of the important moral virtues in the growth and development and completion of human societies; but lust, as the opposite point of modesty, causes the fall of the person and the society.

Saadi knows the value of human honor restricted inhumane contacts with people that are rooted in the human soul and his view, the appearance and physical beauty is the criteria for being human and if the human life is based on eating, sleeping, anger, and lust, therefore there is no difference between the people and animals. He knows the mere materialistic view as the temptations of the carnality and downgrading to animal levels and believes that the suppression of this fulsome self will help the man in reaching the level of humanity and nearness to the God. Killing your ego for the beloved is the doctrine or direct path that guides the disciple to its destiny, and it is patience and humility and fighting the carnality; a dangerous way that passes through obstacles. Saadi is a Muslim who knows the Sharia as predominant over the doctrine and its prerequisites. He believes that the path can be paved from the beginning (sharia) to the end (truth) with the aid of various lanterns such as the divine book, recitation, will, love and so on (Yousefi et al., 2016).

In the view of Saadi, there are many people who accept abjection due needs and avarice. In Bustan, contentment and contentment and piety are validated principles that cause happiness. Is not it true that the human beings are captured in their needs? In this book, the intention of contentment is not withdrawal and putting aside any kind of endeavor and trying for life. In Bustan, contentment means standing against the material world and not being submission against it but to be independent and pious. Since the person who is abject to needs, he will be easily disdained. Such contentment caused wealth and not having greed is the way of escaping many humiliations. The man, who does not think but of eating, sleeping, physical needs, and lust, has chosen the method of beasts while humanity is in reaching knowledge and these characteristics are not placed in the "realm of greed" (Zarrintan, Ranjbar, Aslanabadi, \& Zarrintan, 2015). Saadi has a special view regarding the mundane love and calls it sacred and free from lust, and this is why he knows the lustful people as not being aware of the truth. Saadi sees the world, like many other mystics, 
as the place for the epiphany of love and considers any kind of beauty as a beam of divine beauty. Saadi invites people to purify the soul and cleaning the vision is spite of preventing them to look at beautiesincluding the beautiful face.

On the viewpoint of Saadi, "love" is a pure truth that is not mixed withstand, in other words, any attachment shared with us would not be love. Love is not compatible with lust on the one hand and with the righteousness on the other hand. In Saadi's perspective, preoccupation with appearance and body cannot be called love, but it must be named as lust which is the job of foolish people (Yousefi et al., 2016).

That love, in the word of Saadi, encompasses the love to human beings and changes to the love to the humanism and even goes further and includes the love of all the universe and then reaches the divine love shows that he knows love, not as an epiphany of desire in adolescence but a perfection path in all stages of life(Rajabi, 2013).

Lust management strategies from the viewpoint of Saadi hunger and putting aside self-indulgence Since many are greedy because of their desire to eat, he first mentions eating less, and he certainly favors eating via media; neither eating so less that hurting the body nor eating so much that coming out of mouth. Saadi knows self-indulgence as a hurting way which is done by idiots. He even goes further and says: when the man eats like animals, he will downgrade to objects. He knows eating less and getting used to it as the nearness to angles, but there are recommendations first (Yazdani, 2013):

First be humane, and then think of being the angle

Eat as needed if you are a man; is this big stomach for a man or crock?

Saadi states about greed and desire to eat a lot as a suffering adjective and born out of lust as:

Stomach is the rope of hand and the chain of foot

Stomach lovers rarely worship God

Go and purify your soul

The stomach will not be filled but by soil

(Bustan, sixth chapter)

By controlling the appetite, the ability to control and refine desires increases. Everybody should decide about the amount and kind of food:

One should adapt himself to eating less

To make one like that of angles

(Bustan, sixth chapter)

Whoever can come over his self would be successful. This success can be the foreground for the next successes in a relationship with others and serve them (Covey Stephen, 2007).

In another place in Bustan, Saadi says:

Self-indulgent people are not aware that when

The stomach is full, the mind is empty

The eyes and stomach will never be filled

It is better for the stomach to be empty

(Bustan, sixth chapter) 
This is the allusion to the Prophet (PBHU) hadith: "hunger is the light of understanding" (Youssefi, 1990). Moreover, those who end up with overeating will not yield anything except pain and the pleasure of eating will be altered with the punishment after the overeating.

The inside is the place of strength and recitation

Moreover, you think the self is due to materials

The recitation will not be restricted to greed

The self will be restricted hardly

(Bustan, sixth chapter)

Anorexia is one of the factors of the growth and development of the human to reach the humanity. If all the attention of people is paid to eating and wearing and instinctive needs, and do not see anything beyond them, they do not have any reference to animals, and in fact, they ignore the world of "humanity."

\section{Avoiding greed}

Saadi Shirazi knows the greed as one of the moral vices in the light of which the character of the person downgrades and the pearl of the human soul is misled to sinkhole of misfortune:

Greed makes the contentment infamous

He loses much to grasp a few

When you are watered of the river water

Why are you greedy for the melted snow?

Oh man! Go and be less greedy

What do you gain of the long sleeve?

(Bustan, sixth chapter)

In the perspective of Saadi, the greedy man is the captive of his stomach. He gives away his beliefs for the materials and prefers the world to the hereafter. In his point of view, the greed of the human beings is usually due to bread (food) and stomach and it continuously causes his shame.

The wise man should always foresee the result of his deeds and avoid greed, as the characteristics of downgraded people, before making it as a habit and leaving it becomes difficult and train himself to never fall in this trap (Mohammadi \& Ghalandari, 2015). Saadi tells a tale in this regard:

A man was using soil of the tomb

To make bricks out of that clay

He thought of his body for a moment

And told an advice to himself

Why do you like this golden clay? That

One day others would make clay of you

Greed has many mouths open that

They will never be filled with one spoonful

Do not love this worthless clay that

The river of greed cannot be closed with one brick

You are ignorant of losing your life

While thinking of the materialistic world

The dust has made your eyes blind 
The poisons of lust has burnt your life

Clean the ignorance kohl of your eyes

That you will become the kohl of soil the other day

The lack of attachment to the mundane world

Saadi states that the world is not the eternal place and it is disloyal and do not be interested in (Darabpour, 2010).

Oh son! The world is not eternal

Do not expect loyalty of the world

(Bustan, sixth chapter)

Understanding the true nature of the world has motivated Saadi to remember the world as "rented house", "the caravan's oasis", "hotel" and "garden and farm of the hereafter". This point of view is caused by the influence of Islam on Saadi. In the view of this school, "the world is the farm of the hereafter".

In Saadi's utopia, a pious man receives a golden brick and fiction darkens his luminous soul. He leaves his supplications at midnight and goes to the desert because of being drunk. He sees that someone is mourning at a tomb and he thinks with himself:

One was making clay over a tomb

To make a brick out of that dust

Why do you like that golden brick

That one day they make a brick out of you

(Bustan, ninth chapter)

Saadi believes the world is based on cunning and guile, although it expresses with its love with charm, but it is not loyal to anyone.

Do not attach to the world that is a stranger

And there is no hope in its loyalty

It does not worth to love a beloved that

Has a different lover every morning

(Bustan,

first

Chapter)

The independency and rejecting the materialist world is to leave lust in the view of Saadi. Greed should not prevail upon the mystic life. Therefore, one can develop lack of belonging and attachment to material things in any situation. You can be a king and not have the slightest commitment to the mortal affairs.

Be on the position of power and kingdom

But be the mendicant in the codes of principles

(Bustan, first Chapter)

Belonging and commitment to the ephemeral and material things, the obstacle is the way of the Sufis.

Commitment is an obstacle and is fruitless

If you breakchains, you will achieve

(Bustan, third Chapter) 
Eventually, Saadi introduces the love and commitment to God as the most reliable support in the face of earthly events and states: Saadi rejects the pride and attachment to the materials and positions and recalls their incredibility and disloyalty to the people (Darabpour, 2010).

\section{Contentment}

Contentment in dictionary term means "satisfaction, contentment to the little things" (Dehkhoda, 1998). In terminology, it means "content is to take easy thing related to eating, drinking, and wearing and so on and be satisfied with difficulties of any kind. Contentment is one of the praised characteristics of humans and it is so important in the view of Saadi that he has allocated one chapter of Gulistan and one chapter of Bustan to this subject matter. In Bustan, contentment, contentment and piety are validated principles that cause happiness. Is not it true that the human beings are captured in their needs? In this book, the intention of contentment is not withdrawal and putting aside any kind of endeavor and trying for life. In Bustan, the person, who likens himself to a disable fox for help, is disrespected. Chivalry is respected any way (Youssefi, 1990). In Bustan, contentment means standing against the material world and not being submission against it but to be independent and pious. Since the person who is abject to needs, he will be easily disdained. Such contentment causes wealth and not having greed is the way of escaping many humiliations. The man, who does not think but of eating, sleeping, physical needs and lust, has chosen the method of beasts while humanity is in reaching knowledge and these characteristics are not placed in the "realm of greed" (Youssefi, 1990).

Saadi teaches the human beings through anecdotes to be content with their little daily bread and take their soul awayof humiliation andinferiority. The contentment pearl of Saadi internalizes the self-esteem in the human beings. "Our teacher wants to train the spirit of self-esteem and self-respect in people and relieve us from the suppression. So, adhering to the necessities and advises us to the satisfaction with what happens and relying on the self (Newman, 2004). Contentment removes greed and keeps the human dignity and character.

Contentment makes you proud

Greedy head will not be upper than shoulders

Greed makes the contentment infamous

He loses much to grasp a few

When you are watered of the river water

Why are you greedy for the melted snow?

(Bustan, sixthChapter)

Contentment is a blessing that causes people to disregard the greed to any material and wealth and consider satisfaction with little things as the best asset. Saadi mentions that God, the creator of the universe, is not satisfied with the man who is not satisfied with what is given to him (Youssefi, 1990).

Remembering death and seize the life

Remembering death means "Remember, recall" (Dehkhoda, 1998). And in the terminology, it means that "if the person knows that everybody is going to die and his destiny is tomb, and his client is death angle, and his fate is resurrection and heaven or hell, his most important though is death and he dominates his 
plan as birth and death if he is to be wise" (Al-Ghazzali et al., 2015). Human beings have always known the death for others that has caused ignoring it. Saadi talks to us in a friendly way and advises us to seize youth, of the fast passing days of the life and his repentance and regret:

Oh pity! My youth was finished

It was finished with no fruits

Oh pity! We did not achieve anything

We stayed away from truth and ignored it

(Bustan, ninth chapter)

Exemplary scenes that we face in Gulistan and Bustan make us regretful and sorrowful. We regret a lot and murmur "lament of the evil in our souls." We see the world like an inn that "friends have not stayed in and we will not either," and we remember that we will also visit a strange very soon. We recall the lost moments, and we pity that there will be many flowers flourishing without us and spring will come, and friends will sit together, but we are not here (VERDI, 2015).Carpe diem and using the fast pace moments of life before death is the sign of Saadi's wisdom.

Are you aware Oh bony cage that your soul is a bird called breath?

When the bird escapes the cage, you will not be able to turn it back

Be cautious that life is short; to spend a moment with a Wiseman is better

They went, and everybody harvested what he or she planted as only fame

(Bustan, ninth chapter)

Having

modesty

Modesty, in the word, means "passivity and shame and embarrassment, and the astonishment and horror when someone finds your error, flaw or defect" (Dehkhoda, 1998). And in terminology, it means "a dam showing faith and benevolence and people are of three kinds in this position: unaware, wise, and mystics; the unaware are shamed of people, they are tired, the wise are ashamed of angels, they are thrifty, the mystics are ashamed of God, they are antecedent" (Sajâdi, 1992). One of the key tenets of good temper and morality is the modesty associated with wisdom and knowledge and prevents bad behavior in the face of others.

Being modesty of God is for sinning is the main axis of Saadi's discussion regarding modesty. He blames those who sin and is not ashamed of their God.

Someone was doing a sin, and a pious man saw him

He was wet of shame that I am ashamed of you

When the pious man heard him, he became angry and said

Shame on you! Are not you shameful of God and shame me?

Nobody will benefit you; only satisfy God

Shame God like you are ashamed of you and strangers

(Bustan, ninth chapter)

Jihad with self: The purpose of the self is carnality that is the looter of man from the straight path. "And it is the self that desires physical nature and commands to the pleasures and desires of sense and downgrades heart and it resides bad things and is the source of bad morality" (Dehkhoda, 1998). 
Moreover, in the terminology, it means" Greater veil between you and God is the self, there is no truth but the death of self" (Attar, 1866). Saadi reproaches self and believes that if the self-asks you something any moment and rules over you, it forces you to go everywhere and from place to place to fulfill your needs (Youssefi, 1990). It is in line with the Prophet (PBHU) saying that: "self is the biggest enemy that leads you to wrong way. He started the education chapter as:

You are roommate with your enemy

Why do you fight the stranger enemy?

(Bustan, seventh chapter)

Self is a barrier between you and the Lord. God's satisfaction lies in the refusal of carnality and obedience to God's commands and the tolerance with carnality are disobeying God. Saadi's advice is fighting with it by tolerating difficulties and being strict with self to pave the way to God's satisfaction.

One can be human that

First kills the dog of self

If he is free of lust

He will go up to God

(Bustan, sixth chapter)

Saadi says: the obedience to self-will cause to see the wrong deed beautiful in every moment and be distracted from truth (Mohammadi \& Ghalandari, 2015).

Do not obey the lusty self that

It has a beloved for each hour

(Bustan, sixth Chapter)

All this confirms the fact that the self is not worthy of following, but it is noteworthy that it does not mean to torture the body unreasonably. As Saadi noted in his works, Islam is the religion of balance, and fighting self is fighting with unreasonable wants that prevent the person from getting near to God. In the view of Saadi, the people who have followed their welfare regretful and have lived with sins without a moment of regret in the day of resurrection.

What is the benefit of regret?

When you lost your life time

They drink because it is red

However, they have a yellow face of it

Apologize today before it is too late

(Bustan, ninth chapter)

From the viewpoint of Saadi, desires are the obstacles to human growth and sometimes are very dangerous factors, which are like hidden enemies waiting for the human beings.

You are roommate with your enemy

Why do you fight the stranger enemy?

(Bustan, seventh chapter)

The rule and power of wisdom

All actions, emotions and even our abilities are shaped based on the thoughts. Whatever the human thought is more sublime and is more consistent with his perfection nature, he will go to perfection faster. 
Because the healthy wisdom invites the human beings to balance, therefore it can be said that wisdom is one of the effective factors in balancing the sensual desires and taming the human instinct. In short, wisdom is a guide that causes salvation of mankind in case of being followed. Imam Ali (A) says: "benefiting of wisdom is enough for you since it reveals the direct from the misleading path to you" (Sajâdi, 1992). Saadi finds the solution to fighting self, based on religious beliefs and his intellectual thinking, in the powerful hand of wisdom. He believes that not only is there no conflict between reason and religion, but both of them stand on a common position. Saadi knows the reason and religion together. In his view, whatever is a force by the Islamic Sharia is compatible with rational laws (Saadi, 2006).

Where is it that ration and reason rule?

That Wisemans sell their beliefs to desires

(Bustan, second chapter)

Regarding the emphasis on the rule of wisdom, Saadi likens the human nature to a country that man is asking; wisdom is a minister; satisfaction and virtue are its free people and whim is the thief of its property. In this country, the reason that is the minister should rule to restrict the malevolent aristocrat's whims, greed, and revenge. Knowledge and wisdom can weaken the negative forces by ruling the country of human existence (Yazdani, 2013). Saadi knows human dignity established by wisdom. Wisdom gives Saadi the possibility to present the policy needed to honest and pious people.

Repentance

The word repentance means: "Return of the sin, abandonment of ugly work" (Dehkhoda, 1998). Moreover, in terminology, it means "it is the opposite of doing sins, it is repentance and regret, and the origin of repentance means to return, and it means a return to God." While making the heart away from sins and returning to God and as a result leaving sins in future and compensate for the sins, the truth of repentance goes back to three things: 1. the strength of faith and the light of certainty, 2.repentance and regret and 3.Leave what cause committing sins" (Yousefi et al., 2016). Repentance is one of the important pillars of moral teaching and training of Saadi, and it is also one of the important lessons is mystical training. In the ninth chapter of Bustan, Saadi invites people to repent and return to the truth. Throughout the repentance chapter, he invites the man to awareness and regret of sins by presenting concepts such as negligence of death, the instability of the world, the stability of hereafter, remembering death, the supervision of God on our deeds and shame of him, the mediatory of Prophet and Imams and makes them more tangible by bringing tales. The following tale is an interesting one in which Saadi makes ready for repentance:

One spent a night to play until his call was loud

He slept restlessly at night, not to be disrespected in the morning That if he has done sin at night, he would not be infamous tomorrow

The day of resurrection one is saved who has not committed a sin Why do you afraid if you like repentance, the door is open to you Ask the almighty God to forgive you at night when you sin in day $\mathrm{He}$ is the creator of you from nothing, and then he can forgive you

If a man asks him for forgiveness and if he cries of repentance 
Whoever came regrettably to him, the flood of repentance purified him

God does not disrespect anyone that begs repentance crying

(Bustan, ninth chapter)

After inviting the sinful to man to repentance, Saadi talks of the method and advises as such: when the flames of sin devour the human, the regretful man should pray for God and quell the flames with tears. His thought in repentance and returning to God is ornamented with faith and attachment to God (Saadi, 2006). The world of Saadi is the pleasant ideal world which is associated with the balance of body and soul, peace and security, religion and materials and the eternal kindness of God to his creatures and the door of repentance is always open to people and sins are covered from eyes and the sinful man is hopeful (Sameei Guilani, 2001).

2-13-9: Controlling the lust by the youth from the viewpoint of Saadi

Youth is the period of passion, love, power, inexperience and the victory of affection and senses both in life and in social and emotional matters. Youth is fleeting and destroying it does not leave but sorrow and regret after death. It has been narrated from the Prophet that: "losing chances is sad." Saadi knows two things as the most important for this period: one is knowledge and practice, and the other is avoiding lust and desires. According to him, knowledge should be associated with piety and religion. About sexual instinct, Saadi believes that: this rebellious desire is embedded in human beings by the wisdom of God, and it is controlled but in its legitimate form or through patience. Saadi recommends forbearance about lust and sexual life. He believes that as science provides thoughts' independence, forbearance also provides physical enrichment. With his knowledge of human nature and the inability of most people to harness instincts due to the public and inclusive interest society, he calls for marriage and family formation. Saadi has talked about issues related to the family in different ways. One of his educational sermons in matters related to the family is to get married and avoid free relations. Maybe it is difficult for us, who live in the $21^{\text {st }}$ century, to picture the free sexual relationships in Iran around 900 years ago in which Islamic and religious rules were being followed strictly; but Saadi explicitly mentions it and calls it as "Shahid bazi" and prefers marriage to this kind of relationship. Saadi talks about this subject in the seventh chapter of Bustan as:

The Shahid will destroy your life, go and marry a woman

It is not worthy to love a flower that has a nightingale each day

If she made her the candle of any feast, do not turn around her like a butterfly

(Bustan, seventh chapter)

Saadi has mentioned to the wife selection and conditions that are necessary for women and knows modesty as before facial beauty. Saadi emphasizes the compatibility and love between the couples as well as the piety and sympathy of the wife and stats that: (Sajâdi, 1992)

A good pious woman, Go and knock five times on the door (pray) if

You have problem every day, do not worry that people develop and have friends

A poor man will become a king if he has a good and compatible wife

If you have a sympathetic woman at night, God will have a kind look at them 
(Bustan, seventh chapter)

Lust management in the view of Saadi

Affection management cannot be found with the exact wording of the contemporary scholars in his works of art, but with a little accuracy, the characteristics and aspects of affection management can be easily understood in his works. Affection management provides a foreground that the aspects of human character such as mood, feelings, affections, and emotions develop rationally together and paves the way for the sublime humanistic emotions. By contemplating in Bustan, one can infer that Saadi knows the root of managing stresses and the dominance over the self in the religious and theological beliefs. Saadi advises to religious ideas more than anything.In his view, morality and religious teachings more important Sufism. It seems that Saudi knows religious life as a supplement to social life (Torabi, 1997).

\section{Discussion}

All social problems are seen as a chain in the desirable world of Saadi, away from unilateralism, and he provides his own special solutions to solve the problems of every section from the government to the problem of poverty in society, man's relationship with God, human emotions such as love or admire the beauty and so on. The interesting point is that Saadi does not want to create a one-dimensional manor deny certain aspects of human existence. He, like Hafiz, also knows the man to be a multi-dimensional creature with various needs that a plan for his happiness should present to him based on all his physical and mental aspects of existence. It is not worthy to present a plan based on the suppression of some needs as some have done. This is why love, in both its earthly and heavenly forms, has a special position in the world of Saadi alongside with religious, moral and didactic issues.

The man, who has strong spiritual aspect, will always know God as his friend. Saadi is aware of this fact that the world is not eternal; it is a place where all its residents get old with the passage of time with all their belongings and become out- dated, and they finally die. If the satisfaction and happiness of the man are in earning more wealth, he is a runner that will never reach the end and do not find spiritual peace. The individual belief system, which is the captive of its materialistic view, is like dreams that are considered real in sleep and after awakening, their fakeness is explicitly revealed. Saadi asks people to try to surpass the animal aspect of the existence and reach high levels of mystical and humanistic perfection (Nasr Esfahani, 2011).

\section{References}

Ahmadi, J. (2001). Excitement, Emotion and Non-verbal Communication. (4 ed.). Shiraz: Rahgosha.

Al-Ghazzali, A. H. M., Daniel, E. D., \& Field, C. (2015). The alchemy of Happiness: Routledge. Ali, A. J., \& Al-Owaihan, A. (2008). Islamic work ethic: a critical review. Cross cultural management: An international Journal, 15(1), 5-19.

Attar, F. S. (1866). Tazkirat-ul-auliya: The Asiatic Society Of Bengal, Kolkata.

Bar-On, R. (2006). The Bar-On model of emotional-social intelligence (ESI). Psicothema, 18.

Covey Stephen, R. (2007). Eighth Habit From Effectiveness to Greatness. Transl. from English. M.: Harvard Business Review. 
Darabpour, E. (2010). The mystical reflections of Saadi in Bostan. Basic scientific journal of Persian Language and Literature (Mysticism orientation) Adabestan, first year, the second issue.

Dehkhoda, A. A. (1998). Dehkhoda dictionary. Second Sdition, 1377.

Dunham, G. (2008). Emotion Skills Falnes and Marital Satisfaction Unpublished Doctorral Disseration. University of okran, 53-68.

Farmahini Farahani, M. (1999). Descriptive Dictionary of Educational Sciences. Tehran: shabahang.

Gross, J. J. (1998). The emerging field of emotion regulation: An integrative review. Review of general psychology, 2(3), 271.

Härtel, C., Kibby, L., \& Pizer, M. (2004). Intelligent emotions management: Routledge, London.

Johnson, J. A., Carroll, J., Gottschall, J., \& Kruger, D. (2008). Hierarchy in the library: Egalitarian dynamics in Victorian novels. Evolutionary Psychology, 6(4), 147470490800600414.

Lotfabadi, H. (2007). Developmental Psychology (2) Tehran: Samt Press.

Misbah, A. (1995). Developmental psychology (1). Tehran: SAMT.

Misbah Yazdi, M. (2005). Morality in Quran. Qom: Publication of Imam.

Mohammadi, P., \& Ghalandari, K. (2015). Social Stratification and Negation of Ethnocentrism in Saadi's Gulistan and Bustan. IAU International Journal of Social Sciences, 5(2), 41-50.

Nasr Esfahani, A. (2011). Review and evaluate the constructive criticism from the viewpoint of Saadi and compare it with the views of Western scholars. Kavoshnameh Quarterly, twelfth year(22).

Newman, R. J. (2004). Selections from Saadi's Gulistan: Alhoda UK.

Plutchik, R. (1980). Emotion: A psychoevolutionary synthesis: Harpercollins College Division.

Qaemi, A. (1991). The Background for Training. Tehran: Amiri.

Rahnema, A. (2000). An Islamic utopian: A political biography of Ali Shariati: IB Tauris.

Rajab Nasab, L. (2014). Theological views of Saadi on moral statements in Golestan. Cultural Festival of teacher literature, a celebration of Saadi, Tehran, Iran figures Commemoration Secretariat.

Rajabi, M. (2013). Saadi's outlook toward envy as the ethical vice in light of Alfred Adler's theories Akbar shaabani. New York Science Journal, 6(9), 88-91.

Rypka, J. (2013). History of Iranian literature: Springer Science \& Business Media.

Saadi, M. a.-D. A. (2006). The Koliat of Saadi. Corrected by Mohammad Ali Foroughi, Tehran: Hermes, the center of Saadi studies Safa, Zabihullah (1994). The history of Literature in Iran. Tehran: Ferdows publications.

Safa, Z. (2000). History of literature in Iran. Tehran: Ferdous.

Sajâdi, J. (1992). Farhang-e Estelahat va Ta'birat-e Erfani: Dictionary of mystical terms \& expressions: Tehran, Iran: Tahuri.(Original work published 1370).

Sameei Guilani, A. (2001). Tolerance and motion: two distinct Saadi's characteristics, edited by Kamal Sarvestani Shiraz.

Senobary, S. (2011). The role of emotion in Quran teaching. Paper presented at the The third conference on Quran Strategies in educating human beings. Saber Quran training center.

Shariatmadary, A. (2005). Islamic Training (20 ed.). Tehran: : Amir Kabir publication. 
Torabi, A. (1997). Sociology of Persian literature. Tabriz, Frough Azadi publication. VERDI, P. Z. (2015). THE STUDY OF LIFE AND WORKS OF SAADI, ACCORDING TO HIS POEMS. Paper presented at the INTERNATIONAL CONFERENCE OF PURE WISDOM, Iran.

Yazdani, S. (2013). A Study of People's Beliefs in Saadi's Anthology Golestan. Anthropologist, 15(3), 291-297.

Yousefi, A. R., Keshtiaray, N., \& Khajehpour, L. (2016). Anger and its Management Strategies in Saadi's Bustan. Türk Psikoloji Dergisi, 31(77).

Youssefi, G. H. (1990). Saadi's Bustan correction, Tehran: Khwarizmi publications Mohajerani, S. Ataulla (1999). Saadi, the poet of tolerance and kindnees. Saadi study journals. Second volume.

Zarrintan, S., Ranjbar, F., Aslanabadi, S., \& Zarrintan, M. H. (2015). Bani Adam: Saadi Shirazi (AD 1184-1283/1291) and the concept of empathy. Child's Nervous System, 31(8), 12111212. 